\title{
Potential Inhibitors for SARS-CoV-2 and Functional Food Components as Nutritional Supplement for COVID-19: A Review
}

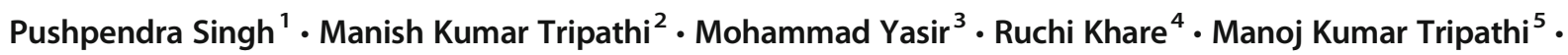 \\ Rahul Shrivastava ${ }^{4}$
}

Accepted: 28 September 2020 / Published online: 10 October 2020

(C) Springer Science+Business Media, LLC, part of Springer Nature 2020

\begin{abstract}
The severe acute respiratory syndrome is a viral respiratory infection and commonly called as COVID-19, caused by severe acute respiratory syndrome coronavirus-2 (SARS-CoV-2). It widely transmitted through direct or indirect contact. Currently, no specific treatment against SARS-CoV-2 are available; only prevention and supportive strategy are the preventive measures. The present review emphasizes the latest research related to COVID-19 and SARS-CoV-2 virus as well as the current status of potential inhibitors identified. Recent interest in SARS-CoV-2 has focused on transmission, symptoms, structure, and its structural proteins that exhibit promising therapeutics targets for rapid identification of potential inhibitors. The quick identification of potential inhibitors and immune-boosting functional food ingredients are crucial to combat this pandemic disease. We also tried to give an overview of the functional food components as a nutritional supplement, which helps in boosting our immune system and could be useful in preventing the COVID-19 and/or to improve the outcome during therapy.
\end{abstract}

Keywords COVID-19 $\cdot$ SARS-CoV-2 $\cdot$ Food ingredients $\cdot$ Immune-boosting $\cdot$ Potential inhibitors

\section{Introduction}

In December 2019, a pandemic outbreak of coronavirus disease (COVID-19) occurred, it is a global health emergency caused by novel coronavirus 2019-nCoV. According to the reports, COVID-19 is emerged from China, giving health threat to the public around the globe since December 2019

Pushpendra Singh and Manish Kumar Tripathi both the Authors Contributed Equally, Joint First Author

Rahul Shrivastava

shrivastavarm1972@gmail.com

1 ICAR - National Institute of High Security Animal Diseases, Bhopal, Madhya Pradesh 462021, India

2 Department of Biophysics, All India Institute of Medical Sciences, New Delhi 110029, India

3 Department of Nephrology, All India Institute of Medical Sciences, Bhopal, Madhya Pradesh 462020, India

4 Department of Biological Science \& Engineering, Maulana Azad National Institute of Technology, Bhopal, Madhya Pradesh 462003, India

5 Agro Produce Processing Division, ICAR - Central Institute of Agricultural Engineering, Bhopal, Madhya Pradesh 462038, India
$[1,2]$. COVID-19 is a severe respiratory infectious disease which transmitted from human to human through respiratory droplets; it also spreads through airborne droplets and by the direct contacts of peoples [3, 4]. Individuals exposed to SARS-CoV-2 infection may require 1 to 14 days before developing symptoms or may remain asymptomatic [5]. The most common symptoms of COVID-19 are fever (91\%), tiredness (73\%), dry cough (52\%) [6] although this disease can be severe and even fatal. COVID-19 has posed a high risk to global public health. According to the weekly epidemiological update of the World Health Organization, 30,675,675 cases have confirmed, and 954,417 death globally. The coronavirus is affecting more than 200 countries and territories around the world, Americas (15,466,584 cases and 527,837 deaths), South-East Asia (6,073,462 cases and 101,700 deaths), Europe (5,195,853 cases and 229,802 deaths), Eastern Mediterranean (2,215,733 cases and 57,641 deaths), Africa (1,145,397 cases and 24,757 deaths), Western Pacific (577,905 cases and 12,667 deaths), are infected region globally, as of 20 September 2020 [7]. In the International Committee on Taxonomy (ICT) of Viruses, a research group called Coronaviridae Study Group (CSG), which has established for the classification of virus and taxon nomenclature. This group recognized this new type of virus as a severe 
acute respiratory syndrome-related coronavirus (SARS-CoV2), previously it was termed as 2019 novel coronavirus (2019$\mathrm{nCoV}$ ) [8].

Due to this new emerging COVID-19, currently, there is no specific antiviral drugs or vaccines, and no specific monoclonal antibodies are available for its therapeutics purpose. As the disease spreads, efforts are being made to decrease its spread through available public health interventions based on the isolation, quarantine of patients and tracing of contacts and travelling history. Antiviral drugs and cocktail of anti-malaria, anti-swine flu, and anti-HIV drugs managed in a while can reduce its infectiousness till the onset of next symptom; this may protect other people by decreasing virus shedding frequency in the respiratory secretions of patients. Several therapeutic possibilities and supportive systems are available for the treatment of COVID-19 are based on the previously applied treatment in SARS-CoV and MERS-CoV.

As the cases of COVID-19 infections rising continuously, a healthy lifestyle along with the daily hygienic precautions such as washing hands, social distancing, exercising and getting enough sleep are some essential factors which help in the declined risk of infection. Intake of a healthy diet will help to boost our immune system is also a favorable step to combat this pandemic disease. It is important to note that no research has evidenced the role of food substituent in fighting, specifically against the COVID-19 infection. However, some previous studies have found that certain functional foods intake can improve our health and supports our body to fight against certain invasive viruses. The immune system plays an essential role in the protection of the host body from infectious agents that exist in the environment (bacteria, viruses, fungi, parasites) and from other noxious insults. As role of functional food in the strengthening of our immune system has been marked, frame and focus of research have been shifted towards the designing of new functional foods which boost our immunity. In this review, we have explained the transmission, symptoms, structure of SARS-CoV-2 and characteristics of the structure protein targets which suggest its promising therapeutic target and can be used to identify and develop a potential inhibitor and diet functional component in the management of COVID-19 caused by SARSCoV-2.

\section{Transmission of COVID-19}

Coronavirus disease 2019 (COVID-19) is a pneumonia-like respiratory disorder caused by a novel coronavirus (also known as severe acute respiratory syndrome coronavirus 2 , or SARS-CoV-2). The transmission of this severe respiratory infection occurs mainly by direct contact between person to person through respiratory droplets, and it can also be transmitted through airborne droplets $[3,4]$. China health officials have approved some evidences of its lateral chain transmission and suggest sustained human-to-human transmission by involving four "generations" (where a primary human source of SARS CoV-2 virus has affected another individual, who then act as carriers and transmit the infection to several other individuals) $[9,10]$. The respiratory droplet transmission occurs when potentially infective droplets of a patient with respiratory symptoms come in close contact (within $1 \mathrm{~m}$ ) with a healthy person then their coughs or sneezes enhances the risk of infection to that person. Therefore, the spread of COVID-19 virus is possible through direct contact with infected people and by indirect contact with the surfaces of the immediate environment or with foreign objects used by the infected person [11].

\section{Symptoms of COVID-19}

The person infected with COVID-19 may be sick with SARS-CoV-2 form 1 to 14 days before developing symptoms [5]. The most common and mild symptoms of coronavirus disease (COVID-19) are high body temperature or fever, tiredness, and dry cough with a rate of expression of 91 , 73 and $52 \%$, respectively [6]. In some patients, other uncommon symptoms like aches and pains, nasal congestion, runny nose, sore throat or diarrhoea have also been observed. Although, disturbed consciousness, headaches and paraesthesia are also seen in COVID-19 patients, the genome sequencing analysis of cerebrospinal fluid revealed the presence of SARS CoV-2 virus in the COVID-19 positive patients. The pathology of coronavirus invasion is still unknown but it causes direct injury or indirect injury like hypoxia injury, immune injury and other injuries to the immune system. These injuries lead to infectious toxic encephalopathy, viral encephalitis, and acute cerebrovascular disease which take the patient into more severe stage [12]. According to the severity of COVID-19 infection, some patients require admission to an intensive care unit (ICU), in which the recovery rate is about $80 \%$ without requiring any special treatment [6]. More rarely, the disease can be severe and even fatal. Older people and the peoples who have other medical problems (such as asthma, diabetes, or heart disease) are more susceptible to becoming severely ill $[13,14]$.

\section{Structure of SARS-CoV-2}

Coronaviruses (SARS-CoV-2) is a member of family Coronaviridae, from order Nidovirales, and the genus is Beta coronavirus [8]. It is the seventh coronavirus known to infect humans in which viruses like SARSCoV-2, SARS-CoV, and MERS-CoV are known to cause severe disease, whereas HKU1, NL63, OC43 and $229 \mathrm{E}$ are known to cause disease with mild symptoms [15]. The coronavirus name was derived from the Latin word "corona" which means "crown" depicting 
the crown-like structure of the viral particle. Morphologically, coronaviruses have non-segmented positive-sense, single-stranded ribonucleic acid (ssRNA) enveloped by structural proteins. The surface of this virus is associated with the club-shaped protein called spikes observed under the two-dimensional transmission electron microscopy [16]. Coronavirus has the largest genome size among all known RNA viruses, and SARS-CoV-2 sizes vary from 29.8 to $29.9(\mathrm{~kb})$ in length $[17,18]$. The SARS-CoV-2 genome is composed of four major structural proteins (Fig. 1), non-structural proteins and some other additional proteins which are essential to produce a structurally whole viral particle and also required for host cell entry, and subsequent viral replication causes coronavirus disease 2019 [19].

\section{Structural Proteins}

The details of SARS-CoV-2 viral particles contain four main structural proteins as spike $(\mathrm{S})$ protein, nucleocapsid $(\mathrm{N})$ protein, membrane $(\mathrm{M})$ protein, and the envelope $(\mathrm{E})$ protein $[4$, $19,20]$.

\section{Spike (S) Protein}

SARS-CoV-2 is known as coronavirus, which has covered their outer membrane surface with a crown-like spikes protein. Initial work has focused on these spike proteins of SARSCoV-2 because they have to play an essential role in the receptor host recognition, cellular attachment and entry to the host cells. To form the distinctive "corona", or crown-like appearance spike proteins assembled into homo-trimeric units on the virion surface [21]. The spike proteins contain two domains: an N-terminal domain denoted as $\mathrm{S} 1$, is responsible for receptor binding, and a C-terminal called $\mathrm{S} 2$ domain which is accountable for the fusion of the viral and cellular membranes to transfer the virus into the host body [22]. This Spike protein facilitates the invasion of SARS-CoV-2 to the host body via attachment mediated by the receptor-binding domain (RBD) located on head of S1 to an angiotensinconverting enzyme 2 (ACE2) receptor protein present on the membrane surface of host cells [23].

\section{Nucleocapsid (N) Protein}

SARS-CoV-2 nucleocapsid (N) protein plays a significant role in the virus replication cycle, modulating the host cell metabolism and self-assembly to form mature viral particle [24]. The primary function of nucleocapsid protein is to enclose $30 \mathrm{~kb} 5^{\prime}$-capped single positive-strand viral genome RNA molecule, into the ribonucleoprotein (RNP) complex which is also known as capsid on $\mathrm{N}$-terminal domain $(\mathrm{N}$ NTD) [25]. Virus self-assembly is a fundamental part of the packaging of its protein forming Ribonucleocapsid complex. In addition to this function, the nucleocapsid protein of the coronavirus found to serve as regulatory roles in host cell life cycle and modulate the cellular machinery of a host [26]. Crystal structure of SARS-CoV-2 nucleocapsid $(\mathrm{N})$ protein $\mathrm{N}$-terminal domain (N-NTD), show the specific target sites which can help to identify the potential inhibitors for SARSCoV-2 nucleocapsid protein.

\section{Membrane (M) Protein}

SARS-CoV-2 membrane (M) protein has three surface transmembrane domains, and its structure helps to provide flexibility in the viral membrane curvature, which further binds to the nucleocapsid protein [27]. However, there is still not known about the crystal structure of SARS-CoV-2 membrane (M) protein. It is the most abundant viral protein and has a significant role in infection and the assembly of mature virus particles [28].

Fig. 1 Structure of SARS-CoV-2

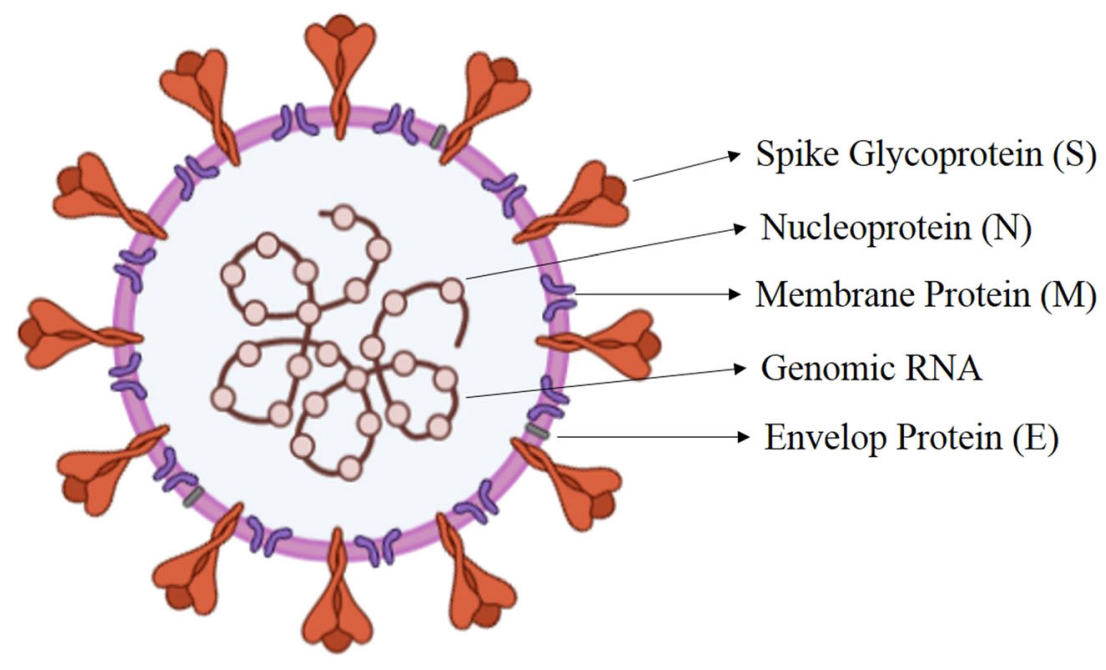




\section{Envelope (E) Protein}

SARS-CoV-2 envelope (E) protein is situated near the spike (S) protein and reported to oligomerize and form ion channels [29]. In contrast, envelope protein has an essential role in the assembly of the mature viral particles [30]. This enveloped protein comprised short hydrophilic terminal followed by the large hydrophobic transmembrane domain and terminates with long hydrophilic carboxyl end belong to SARS-CoV-2 virus of the Coronaviridae family [18].

\section{Diagnostic of COVID-19}

COVID-19 diagnostic comprises examining samples that indicate the presence or absence of SARS-CoV-2. The two broad categories of diagnoses are, a viral test for the current infection through polymerase chain reaction (PCR) and antigen detection in the nasopharyngeal swab, or antibody test for the past presence of the virus through antibody detection in serum [31].

Viral Test Polymerase chain reaction (PCR) tests are mainly used for direct detection of virus present in the sample by a real-time reverse transcription-polymerase chain reaction (RT-PCR) which is said to be 'gold standard' or confirmatory test or frontline test for COVID-19. RT-PCR is a qualitative test performed for the detection of a viral nucleic acid of SARS-CoV-2 in the sample specimens (where nasal, nasopharyngeal or oropharyngeal swabs, sputum are categorized as upper respiratory sample specimens and lower respiratory tract are the aspirates, bronchoalveolar lavage, and nasopharyngeal wash/aspirate or nasal aspirate) collected from the suspected individuals of COVID-19 [32].

Antibody Test It is also known as serological tests and used to find out the presence of an antibody, which are specific proteins made in response to SARS-CoV-2 infections in our body [33]. An antibody detection may not be able to display if individuals suspected have a current infection, because it can take 1-3 weeks after infection to make antibodies. Antibodies are immunoglobulin proteins that help to fight off COVID-19 infections and generally provides protection against the disease in future.

\section{Recent Therapeutics Strategies for COVID-19}

The foremost universal strategy to hold the infection is a "lockdown" approach to breaking a chain reaction of the virus comes in contact with healthy individuals. Although more than a million individuals globally remain confirmed to stay infected with COVID-19, there is not a proven drug or vaccine available yet to control this pandemic situation. In COVID-19, SARS-CoV-2 attacks and dysfunctions multiple organs such as lungs, heart, intestine and blood vessels. In severe infection, this virus evades through the respiratory mucosa and target other cells present in the lining of lungs, inducing respiratory distress which produces cytokine storm systemically and this condition causes a decrease in oxygen levels in the blood and finally to death $[34,35]$. Consequently, timely detection and appropriate treatment of severe cases are of critical importance. Treatment of acute and life-threatening infection of SARS-CoV-2 is accompanied by suggestive therapy and ventilation care in hospital. No antiviral treatment and clinical trial data are supporting for its cure, and more than a hundred active clinical trials are still going on. The antiviral drugs that identified from the previous clinical experience of managing this severe acute respiratory syndrome and other virus infection have been used against the confirmed patients of COVID-19. Several possible treatment therapies, including supportive intervention, antiviral drug, anti-malarial drugs, anticoagulants immune-modulatory agents, nutritional supportive care and convalescent plasma transfusion, have been tentatively applied in the clinical therapy [36]. However, a number of these therapies have provided significant therapeutic benefits in the management of SARS-CoV-2 infection (Table 1).

\section{Functional Foods to Boost the Immune System}

Functional foods are defined as "the dietary items that are modulated to perform one or more targeted functions in the body", so besides providing nutrients and energy, they also provide their benefits in the diet during effective treatment in the diseases by enhancing the physiological response and/or reducing the risk of disease [54]. Many functional foods and components are naturally occurring compound scientifically described to have immune-boosting properties [55]. These natural compounds do not participate in the direct inhibition response against coronavirus, but complete immunity plays an essential role in preventive defence against COVID-19. Studies have reported the use of many prebiotics, probiotics, and ayurvedic products as natural targets which boost immune response. These products reduce the stress level of the body and strengthen the immune response in our body. These functional food components, including the probiotics and micronutrient supplement, helps to maintain the gut healthy by maintaining the microflora and bacterial colonies, claim to immune-boosting properties (Table 2). The functional food compounds, including food ingredients or whole foods, have immuneenhancing features. Micronutrients, probiotics, flavonoids, carotenoids and herbs have been reported beneficial to immune health. Spices like turmeric, cumin, coriander and garlic are also recommended in cooking for boosting the immune system. These spices are seen as health promoters 
Table 1 Possible synthetic inhibitors for the management of COVID -19

\begin{tabular}{|c|c|c|c|c|}
\hline $\begin{array}{l}\text { S. } \\
\text { No. }\end{array}$ & Drug & Target & Action & Reference \\
\hline 1. & $\begin{array}{l}\text { Chloroquine/Chloroquine sulphate/ } \\
\text { Hydroxychloroquine/ Chloroquine } \\
\text { phosphate }\end{array}$ & ACE2 & $\begin{array}{l}\text { Chloroquine rises the endosomal } \mathrm{pH} \text { required for virus/cell fusion, } \\
\text { as well as interfering with the glycosylation of cellular receptors of } \\
\text { SARS-CoV-2. Efficacy against COVID-19 pneumonia might be due to } \\
\text { both antiviral and anti-inflammatory properties. }\end{array}$ & [37-39] \\
\hline 2. & Remdesivir & $\begin{array}{l}\text { RNA Dependent } \\
\text { RNA } \\
\text { Polymerase }\end{array}$ & $\begin{array}{l}\text { A nucleoside analogue which incorporates into the nascent viral RNA } \\
\text { chains and results in premature termination. }\end{array}$ & [37] \\
\hline 3. & Fedratinib & JAK2 inhibitor & $\begin{array}{l}\text { TH17 type reaction play role to the cytokine storm in pulmonary viral } \\
\text { infection which outcomes in tissue damage and probable promotes } \\
\text { pulmonary edema including SARS-CoV-2 infection, } \\
\text { whereas JAK2 inhibitor Fedratinib can suppress the production of } \\
\text { TH17 signature cytokines (IL6). }\end{array}$ & {$[40]$} \\
\hline 4. & Losartan and Telmisartan & $\begin{array}{l}\text { Angiotensin } \\
\text { receptor } 1 \\
(\mathrm{AT} 1 \mathrm{R})\end{array}$ & $\begin{array}{l}\text { ACE2 is a binding site for SARS-CoV-2, indicating that angiotensin } \\
\text { receptor blockers could be a therapeutic strategy for SARS-CoV-2 } \\
\text { infections. }\end{array}$ & [41] \\
\hline 5. & Lopinavir and Ritonavir & & Lopinavir-ritonavir treatment reduce mortality with serious COVID-19. & {$[42,43]$} \\
\hline 6. & rhACE2 & ACE2 blocker & $\begin{array}{l}\text { Recombinant Human Angiotensin-Converting Enzyme-2 (rhACE2) is } \\
\text { bound to SARS-CoV-2 Spike-protein, thus protects host lungs from } \\
\text { virus attack. }\end{array}$ & {$[44,45]$} \\
\hline 7. & Baricitinib & JAK inhibitor & $\begin{array}{l}\text { Baricitinib attenuates pro-inflammatory response by constraining JAK } \\
\text { and blocks virus entering into the host cells through inhibiting JAK1 } \\
\text { and JAK2. }\end{array}$ & [46] \\
\hline 8. & Favipiravir & $\begin{array}{l}\text { RNA-dependent } \\
\text { RNA } \\
\text { polymerase }\end{array}$ & $\begin{array}{l}\text { Favipiravir is a novel RNA-dependent RNA polymerase (RdRp) inhibitor } \\
\text { which has faster viral clearance and better chest imaging change. }\end{array}$ & {$[47,48]$} \\
\hline 9. & Elbasvir & Main protease & $\begin{array}{l}\text { Identified to have inhibitory activities against SARS-CoV-2 main prote- } \\
\text { ase. }\end{array}$ & [49] \\
\hline 10. & Azithromycin & CD147 & $\begin{array}{l}\text { Patients taking the azithromycin combination with hydroxychloroquine } \\
\text { were virologically cured within six days of treatment. }\end{array}$ & {$[50,51]$} \\
\hline 11. & Tocilizumab & IL-6 receptor & $\begin{array}{l}\text { Tocilizumab is a humanized recombinant monoclonal antibody that acts } \\
\text { as an IL-6 receptor antagonist. }\end{array}$ & {$[52]$} \\
\hline 12. & Dexamethasone & $\begin{array}{l}\text { Glucocorticoid } \\
\text { receptor }\end{array}$ & $\begin{array}{l}\text { Dexamethasone effectively alleviated the pulmonary inflammatory } \\
\text { reaction. }\end{array}$ & {$[53]$} \\
\hline
\end{tabular}

as they promote monoamine and gamma-aminobutyric acid neurotransmission, which are essential part of the nutrition [56]. Some studies have also suggested the essential need to develop specific nutrient-based functional foods which may play a vital role in fighting against metabolic disorders, infection or diseases [57].

Micronutrients, including vitamins and minerals, are the biological or biochemical compounds required in relatively small quantities or in trace amount where they participate in the metabolic reactions and essential biochemical pathways. The deficiency of such compounds leads to disturbance in the function in our body, which results in the weakening of host immune response [58]. A study reported the deficiency of micronutrient Selenium (Se) marked by a reduction in immune function [59]. Selenium supplementation has known for its immune-stimulant effect, which includes enhancement of activated T cells (cytotoxic lymphocytes) and an NK-cell activity [60]. Destruction of sensory cells by SARS-CoV in oral mucosa might be the cause of parageusia. Chelation of zinc through immune mechanisms results in the alteration of zinc homeostasis in oral gustatory cells. This mechanism may result in the taste disturbances as observed by zinc insufficiency [61]. Thus, Zinc supplementation could also play an important role in prophylaxis and the treatment of COVID-19 $[62,63]$. The blood sample reports of COVID-19 positive patients showed greater alteration in parameters like creatinine, neutrophil count and blood urea. They also indicated elevated concentration of pro-inflammatory cytokines IL-6, and TNF- $\alpha$. Moreover, oxidative stress may cause an altered lung immune response, which leads to severe lung infections. The dietary supplements are rich source of flavonoids, antioxidants, polyphenols which helps in boost the immune system [64-66]. Golden milk is a milk-based drink (half teaspoon turmeric powder in $150 \mathrm{ml}$ hot milk) - once or twice a day is said to be an immunity booster. Haridra (Curcuma longa Linn.), i.e., turmeric has an active constituent of curcumin which blocks cytokine release, has most notably key proinflammatory cytokines, interleukin-1, interleukin-6 and tumour necrosis factor- $\alpha$, which is advisable to take with milk. The suppression of cytokine release by curcumin correlates 
Table 2 Functional food ingredients reported boosting immune health

\begin{tabular}{|c|c|c|c|}
\hline S. No. & Major food ingredient & Mechanism of immune-boosting & Reference \\
\hline 1. & Micronutrients (Selenium) & Effect immunostimulant activities. & {$[60,74]$} \\
\hline 2. & Probiotics & Modulate the immune system & {$[75]$} \\
\hline 3. & Vitamin A, C, E & Prevent damage to the immune cells (antioxidant). & {$[55]$} \\
\hline 4. & Vitamin D supplements & Reducing the risk of respiratory tract infections by COVID-19. & {$[71]$} \\
\hline 5. & $\begin{array}{l}\text { Omega-3 fatty acids supplements } \\
\text { (EPA and DHA) }\end{array}$ & Reduce COVID-19 severity and recovery of patients infected with SARS-CoV-2 & {$[68]$} \\
\hline 6. & Flavonoids & Modulate the immune system (antioxidant and anti-inflammation properties). & {$[76,77]$} \\
\hline 7. & Carotenoids & Regulate immune function (antioxidant, gene regulation and apoptosis). & {$[78]$} \\
\hline 8. & Herbs & Stimulate immune response. & [79] \\
\hline 9. & Curcumin & Anti-inflammatory compound. & {$[80]$} \\
\hline 10. & Highly viscous polysaccharide & Immunomodulatory properties. & {$[81]$} \\
\hline 11. & Dry biofortified phytoactive-protein & Immunoprotective compound. & {$[82]$} \\
\hline 12. & Tea components & Anti-influenza virus activity. & {$[83]$} \\
\hline
\end{tabular}

with clinical improvement in experimental models of flu and infectious diseases. It can be compared with COVID-19, where a cytokine storm plays a significant role in the mortality [67]. Although, higher consumption of omega-3 fatty acids has evidenced the reduced inflammation induced immune response. According to a study, eicosapentaenoic acid (EPA) and docosahexaenoic acid (DHA) have shown their potential in reducing the oxygen saturation, treatment days, need for the ventilators and also the rate of mortality [68]. Prebiotics are the food supplements ingredients which are composed of oligosaccharide that are not digestible by the host health during selective stimulation of the growth and activity of gut microbiota. Probiotics interact with the host system and gives strength and resistance in the body through microbiota residing in our body with a commensal relationship. The role of probiotics in immune-boosting is supposed to be achieved by the indirect stimulation of cytokine production and modulation in gastrointestinal function. Probiotic bacteria can interact with our gut microbiome to reinforce our immune system, increase the immune response system and promote the specific immune signalling with several physiological and clinical importance [69].

Some vitamins like vitamin A, C, E, flavonoids and carotenoids are readily available in diet and works as an antioxidant for scavenging the oxidative free radicals. Vitamin D supplement was safe in preventing acute respiratory tract infections and influenza [70, 71]. Some naturally occurring functional food compounds, such as flavonoids and carotenoids have been reported as a potent antioxidant and anti-inflammatory agents, which helps to strengthen the immune system [72]. The two fundamental immune-boosting properties associated with fruit and vegetables are antioxidant and anti-inflammation, which are considered to be useful biomarkers for the assessment of human health [73].

\section{Conclusion}

The COVID-19 outbreak spread rapidly worldwide and is an unprecedented crisis for public health. Fighting with current pandemic needs is to take steps for its infection and spread reduction from person to person. However, COVID-19 transmission among the population can be reduced by taking preventive measures. In conclusion, we follow government guidelines and advisories strictly, to clean nearby, regular hand wash, use of mask and maintain social distancing protocol, these things can break the COVID-19 spreading chain and prevent the people from this disease. Lastly, stay at home, stay live and stay aware of daily information on COVID-19 outbreak, issued by the national, state and local public health authority. New drug discovery and drug repurposing against SARS-CoV2 is a challenging task but is essential according to the current scenario. Thus, antiviral drug and vaccine development is necessary to counter this pandemic situation. However, immune-boosting is also another strategy to fight against this disease. Therefore, micronutrients, functional food ingredients like probiotics, herbs, flavonoids, and carotenoids can be considered as natural immunebooster foods. These innovative immune-boosting functional foods fortified with bioactive compounds and antioxidants boost up the immune system. Finally, understanding of structural protein of SARS-CoV-2 may be possibly useful in developing promising therapeutic drugs for COVID-19.

\section{Compliance with Ethical Standards}

Conflict of Interest The authors have no conflict of interest regarding the publication of this article. 


\section{References}

1. WHO, WHO Director-General's opening remarks at the media briefing on COVID-19 - 11 March 2020, https://www.Who.Int/ Dg/Speeches/Detail/Who-Director-General-s-Opening-Remarksat-the-Media-Briefing-on-Covid-19\%2D\%2D-11-March-2020. (2020)

2. Li H, Liu S-M, Yu X-H, Tang S-L, Tang C-K (2020) Coronavirus disease 2019 (COVID-19): current status and future perspectives. Int J Antimicrob Agents 105951:105951. https://doi.org/10.1016/j. ijantimicag.2020.105951

3. Jin Y-H, Cai L, Cheng Z-S, Cheng H, Deng T, Fan Y-P, Fang C, Huang D, Huang L-Q, Huang Q, Han Y, Hu B, Hu F, Li B-H, Li YR, Liang K, Lin L-K, Luo L-S, Ma J, Ma L-L, Peng Z-Y, Pan Y-B, Pan Z-Y, Ren X-Q, Sun H-M, Wang Y, Wang Y-Y, Weng H, Wei C-J, Wu D-F, Xia J, Xiong Y, Xu H-B, Yao X-M, Yuan Y-F, Ye TS, Zhang X-C, Zhang Y-W, Zhang Y-G, Zhang H-M, Zhao Y, Zhao M-J, Zi H, Zeng X-T, Wang Y-Y, Wang X-H, for the Z.H. of W.U.N.C.M. and R.T (2020) Evidence-based medicine chapter of china international exchange and promotive association for medical and health care (CPAM), a rapid advice guideline for the diagnosis and treatment of 2019 novel coronavirus (2019-nCoV) infected pneumonia (standard version). Mil Med Res 7:4. https://doi.org/ 10.1186/s40779-020-0233-6

4. Liu J, Liao X, Qian S, Yuan J, Wang F, Liu Y, Wang Z, Wang F-S, Liu L, Zhang Z (2020) Community transmission of severe acute respiratory syndrome coronavirus 2, Shenzhen, China, 2020. Emerg Infect Dis J 26(6):1320-1323. https://doi.org/10.3201/ eid2606.200239

5. Lauer SA, Grantz KH, Bi Q, Jones FK, Zheng Q, Meredith HR, Azman AS, Reich NG, Lessler J (2020) The incubation period of coronavirus disease 2019 (COVID-19) from publicly reported confirmed cases: estimation and application. Ann Intern Med 172:577582. https://doi.org/10.7326/M20-0504

6. Lei S, Jiang F, Su W, Chen C, Chen J, Mei W, Zhan L-Y, Jia Y, Zhang L, Liu D, Xia Z-Y, Xia Z (2020) Clinical characteristics and outcomes of patients undergoing surgeries during the incubation period of COVID-19 infection. EClinicalMedicine 21:100331. https://doi.org/10.1016/j.eclinm.2020.100331

7. WHO (2020) Coronavirus disease (COVID-19) Weekly epidemiological update. https://www.Who.Int/Docs/Default-Source/ Coronaviruse/Situation-Reports/20200921-Weekly-Epi-Update-6. Pdf?Sfvrsn=d9cf9496_6

8. Gorbalenya AE, Baker SC, Baric RS, de Groot RJ, Drosten C, Gulyaeva AA, Haagmans BL, Lauber C, Leontovich AM, Neuman BW, Penzar D, Perlman S, Poon LLM, Samborskiy DV, Sidorov IA, Sola I, Ziebuhr J, C.S.G. of the I.C. on T. of Viruses (2020) The species severe acute respiratory syndrome-related coronavirus: classifying 2019-nCoV and naming it SARS-CoV-2. Nat Microbiol 5:536-544. https://doi.org/10.1038/s41564-020-0695-Z

9. Wu D, Wu T, Liu Q, Yang Z (2020) The SARS-CoV-2 outbreak: what we know. Int J Infect Dis 94:44-48. https://doi.org/10.1016/j. ijid.2020.03.004

10. Phelan AL, Katz R, Gostin LO (2020) The novel coronavirus originating in Wuhan, China: challenges for Global Health governance. JAMA 323:709-710. https://doi.org/10.1001/jama.2020.1097

11. WHO, Modes of transmission of virus causing COVID-19: implications for IPC precaution recommendations, 29 March 2020. (2020)

12. Wu Y, Xu X, Chen Z, Duan J, Hashimoto K, Yang L, Liu C, Yang C (2020) Nervous system involvement after infection with COVID19 and other coronaviruses. Brain Behav Immun 87:18-22. https:// doi.org/10.1016/j.bbi.2020.03.031

13. Zhou F, Yu T, Du R, Fan G, Liu Y, Liu Z, Xiang J, Wang Y, Song B, Gu X, Guan L, Wei Y, Li H, Wu X, Xu J, Tu S, Zhang Y, Chen
H, Cao B (2020) Clinical course and risk factors for mortality of adult inpatients with COVID-19 in Wuhan, China: a retrospective cohort study. Lancet 395:1054-1062. https://doi.org/10.1016/ S0140-6736(20)30566-3

14. Verity R, Okell LC, Dorigatti I, Winskill P, Whittaker C, Imai N, Cuomo-Dannenburg G, Thompson H, Walker PGT, Fu H, Dighe A, Griffin JT, Baguelin M, Bhatia S, Boonyasiri A, Cori A, Cucunubá Z, FitzJohn R, Gaythorpe K, Green W, Hamlet A, Hinsley W, Laydon D, Nedjati-Gilani G, Riley S, van Elsland S, Volz E, Wang H, Wang Y, Xi X, Donnelly CA, Ghani AC, Ferguson NM (2020) Estimates of the severity of coronavirus disease 2019: a model-based analysis. Lancet Infect Dis 20:669-677. https://doi.org/10.1016/S1473-3099(20)30243-7

15. Andersen KG, Rambaut A, Lipkin WI, Holmes EC, Garry RF (2020) The proximal origin of SARS-CoV-2. Nat Med 26:450 452. https://doi.org/10.1038/s41591-020-0820-9

16. Fehr AR, Perlman S (2015) Coronaviruses: an overview of their replication and pathogenesis. Methods Mol Biol 1282:1-23. https:// doi.org/10.1007/978-1-4939-2438-7_1

17. Guo Y-R, Cao Q-D, Hong Z-S, Tan Y-Y, Chen S-D, Jin H-J, Tan K-S, Wang D-Y, Yan Y (2020) The origin, transmission and clinical therapies on coronavirus disease 2019 (COVID-19) outbreak an update on the status. Mil Med Res 7:11. https://doi.org/10.1186/ s40779-020-00240-0

18. Schoeman D, Fielding BC (2019) Coronavirus envelope protein: current knowledge. Virol J 16:69. https://doi.org/10.1186/s12985019-1182-0

19. Astuti I (2020) Ysrafil, severe acute respiratory syndrome coronavirus 2 (SARS-CoV-2): an overview of viral structure and host response. Diabetes Metab Syndr 14:407-412. https://doi.org/10. 1016/j.dsx.2020.04.020

20. Tripathi MK, Singh P, Sharma S, Singh TP, Ethayathulla AS, Kaur $P$ (2020) Identification of bioactive molecule from Withania somnifera (Ashwagandha) as SARS-CoV-2 main protease inhibitor. J Biomol Struct Dyn. https://doi.org/10.1080/07391102.2020. 1790425

21. Belouzard S, Millet JK, Licitra BN, Whittaker GR (2012) Mechanisms of coronavirus cell entry mediated by the viral spike protein. Viruses 4:1011-1033. https://doi.org/10.3390/v4061011

22. Walls AC, Park Y-J, Tortorici MA, Wall A, McGuire AT, Veesler D (2020) Structure, function, and antigenicity of the SARS-CoV-2 spike glycoprotein. Cell 181:281-292.e6. https://doi.org/10.1016/j. cell.2020.02.058

23. Zhang H, Penninger JM, Li Y, Zhong N, Slutsky AS (2020) Angiotensin-converting enzyme 2 (ACE2) as a SARS-CoV-2 receptor: molecular mechanisms and potential therapeutic target. Intensive Care Med 46:586-590. https://doi.org/10.1007/s00134020-05985-9

24. Kang S, Yang M, Hong Z, Zhang L, Huang Z, Chen X, He S, Zhou Z, Zhou Z, Chen Q, Yan Y, Zhang C, Shan H, Chen S (2020) Crystal structure of SARS-CoV-2 nucleocapsid protein RNA binding domain reveals potential unique drug targeting sites. Acta Pharm Sin B 10:1228-1238. https://doi.org/10.1016/ j.apsb.2020.04.009

25. Chang C, Hou M-H, Chang C-F, Hsiao C-D, Huang T (2014) The SARS coronavirus nucleocapsid protein - forms and functions. Antivir Res 103:39-50. https://doi.org/10.1016/j.antiviral.2013. 12.009

26. Chang C, Sue S-C, Yu T, Hsieh C-M, Tsai C-K, Chiang Y-C, Lee S, Hsiao H, Wu W-J, Chang W-L, Lin C-H, Huang T (2006) Modular organization of SARS coronavirus nucleocapsid protein. J Biomed Sci 13:59-72. https://doi.org/10.1007/s11373-0059035-9

27. Chen Y, Liu Q, Guo D (2020) Emerging coronaviruses: genome structure, replication, and pathogenesis. J Med Virol 92:418-423. https://doi.org/10.1002/jmv.25681 
28. He R, Leeson A, Ballantine M, Andonov A, Baker L, Dobie F, Li Y, Bastien N, Feldmann H, Strocher U, Theriault S, Cutts T, Cao J, Booth TF, Plummer FA, Tyler S, Li X (2004) Characterization of protein-protein interactions between the nucleocapsid protein and membrane protein of the SARS coronavirus. Virus Res 105:121125. https://doi.org/10.1016/j.virusres.2004.05.002

29. Li G, Fan Y, Lai Y, Han T, Li Z, Zhou P, Pan P, Wang W, Hu D, Liu X, Zhang Q, Wu J (2020) Coronavirus infections and immune responses. J Med Virol 92:424-432. https://doi.org/10.1002/jmv. 25685

30. Gupta MK, Vemula S, Donde R, Gouda G, Behera L, Vadde R (2020) In-silico approaches to detect inhibitors of the human severe acute respiratory syndrome coronavirus envelope protein ion channel. J Biomol Struct Dyn 1-11. https://doi.org/10.1080/07391102. 2020.1751300

31. Tang Y-W, Schmitz JE, Persing DH, Stratton CW (2020) Laboratory diagnosis of COVID-19: current issues and challenges. J Clin Microbiol 58:e00512-e00520. https://doi.org/10.1128/JCM. 00512-20

32. Udugama B, Kadhiresan P, Kozlowski HN, Malekjahani A, Osborne M, Li VYC, Chen H, Mubareka S, Gubbay JB, Chan WCW (2020) Diagnosing COVID-19: the disease and tools for detection. ACS Nano 14:3822-3835. https://doi.org/10.1021/ acsnano.0c02624

33. Mathuria JP, Yadav R, Rajkumar, (2020) Laboratory diagnosis of SARS-CoV-2 - a review of current methods. J Infect Public Health 13:901-905. https://doi.org/10.1016/j.jiph.2020.06.005

34. Li L, Li R, Wu Z, Yang X, Zhao M, Liu J, Chen D (2020) Therapeutic strategies for critically ill patients with COVID-19. Ann Intensive Care 10:45. https://doi.org/10.1186/s13613-02000661-Z

35. Sun P, Qie S, Liu Z, Ren J, Li K, Xi J (2020) Clinical characteristics of hospitalized patients with SARS-CoV-2 infection: a single arm meta-analysis. J Med Virol 92:612-617. https://doi.org/10.1002/ jmv. 25735

36. Zhang J, Xie B, Hashimoto K (2020) Current status of potential therapeutic candidates for the COVID-19 crisis. Brain Behav Immun 87:59-73. https://doi.org/10.1016/j.bbi.2020.04.046

37. Wang M, Cao R, Zhang L, Yang X, Liu J, Xu M, Shi Z, Hu Z, Zhong W, Xiao G (2020) Remdesivir and chloroquine effectively inhibit the recently emerged novel coronavirus (2019-nCoV) in vitro. Cell Res 30:269-271. https://doi.org/10.1038/s41422020-0282-0

38. Devaux CA, Rolain J-M, Colson P, Raoult D (2020) New insights on the antiviral effects of chloroquine against coronavirus: what to expect for COVID-19? Int J Antimicrob Agents 105938:105938. https://doi.org/10.1016/j.ijantimicag.2020.105938

39. Gao J, Tian Z, Yang X (2020) Breakthrough: chloroquine phosphate has shown apparent efficacy in treatment of COVID-19 associated pneumonia in clinical studies. Biosci Trends 14:72-73. https://doi.org/10.5582/bst.2020.01047

40. Wu D, Yang XO (2020) TH17 responses in cytokine storm of COVID-19: an emerging target of JAK2 inhibitor Fedratinib. J Microbiol Immunol Infect S1684-1182(20):30065-30067. https:// doi.org/10.1016/j.jmii.2020.03.005

41. Gurwitz D (2020) Angiotensin receptor blockers as tentative SARS-CoV-2 therapeutics. Drug Dev Res. https://doi.org/10. 1002/ddr.21656

42. Cao B, Wang Y, Wen D, Liu W, Wang J, Fan G, Ruan L, Song B, Cai Y, Wei M, Li X, Xia J, Chen N, Xiang J, Yu T, Bai T, Xie X, Zhang L, Li C, Yuan Y, Chen H, Li H, Huang H, Tu S, Gong F, Liu Y, Wei Y, Dong C, Zhou F, Gu X, Xu J, Liu Z, Zhang Y, Li H, Shang L, Wang K, Li K, Zhou X, Dong X, Qu Z, Lu S, Hu X, Ruan S, Luo S, Wu J, Peng L, Cheng F, Pan L, Zou J, Jia C, Wang J, Liu X, Wang S, Wu X, Ge Q, He J, Zhan H, Qiu F, Guo L, Huang C, Jaki T, Hayden FG, Horby PW, Zhang D, Wang C (2020) A trial of lopinavir-ritonavir in adults hospitalized with severe Covid-19. N Engl J Med. https://doi.org/10.1056/NEJMoa2001282

43. Stower H (2020) Lopinavir-ritonavir in severe COVID-19. Nat Med 26:465. https://doi.org/10.1038/s41591-020-0849-9

44. Junyi G, Zheng H, Li L, Jiagao L (2020) Coronavirus disease 2019 (COVID-19) and cardiovascular disease: a viewpoint on the potential influence of angiotensin-converting enzyme inhibitors/ angiotensin receptor blockers on onset and severity of severe acute respiratory syndrome coronavirus 2 infec. J Am Heart Assoc 9: e016219. https://doi.org/10.1161/JAHA.120.016219

45. Barone M, Ucciferri C, Cipollone G, Mucilli F (2020) Recombinant human angiotensin-converting enzyme 2 and COVID-19 acute respiratory distress syndrome: a theoretical or a real resource? Eurasian J Med Oncol 4:139-140. https://doi.org/10.14744/ejmo. 2020.47992

46. Favalli EG, Biggioggero M, Maioli G, Caporali R (2020) Baricitinib for COVID-19: a suitable treatment? Lancet Infect Dis 20:1012-1013. https://doi.org/10.1016/S1473-3099(20)30262-0

47. Cai Q, Yang M, Liu D, Chen J, Shu D, Xia J, Liao X, Gu Y, Cai Q, Yang Y, Shen C, Li X, Peng L, Huang D, Zhang J, Zhang S, Wang F, Liu J, Chen L, Chen S, Wang Z, Zhang Z, Cao R, Zhong W, Liu Y, Liu L (2020) Experimental treatment with favipiravir for COVID-19: an open-label control study, engineering. N Engl J Med. https://doi.org/10.1016/j.eng.2020.03.007

48. Dong L, Hu S, Gao J (2020) Discovering drugs to treat coronavirus disease 2019 (COVID-19). Drug Discov Ther 14:58-60. https:// doi.org/10.5582/ddt.2020.01012

49. Wang J (2020) Fast identification of possible drug treatment of coronavirus disease-19 (COVID-19) through computational drug repurposing study. J Chem Inf Model 60:3277-3286. https://doi. org/10.1021/acs.jcim.0c00179

50. Ulrich H, Pillat MM (2020) CD147 as a target for COVID-19 treatment: suggested effects of azithromycin and stem cell engagement. Stem Cell Rev Reports 16:1-7. https://doi.org/10.1007/ s12015-020-09976-7

51. Gautret P, Lagier J-C, Parola P, Hoang VT, Meddeb L, Mailhe M, Doudier B, Courjon J, Giordanengo V, Vieira VE, Dupont HT, Honoré S, Colson P, Chabrière E, La Scola B, Rolain J-M, Brouqui P, Raoult D (2020) Hydroxychloroquine and azithromycin as a treatment of COVID-19: results of an open-label non-randomized clinical trial. Int J Antimicrob Agents 105949:105949. https:// doi.org/10.1016/j.ijantimicag.2020.105949

52. Cellina M, Orsi M, Bombaci F, Sala M, Marino P, Oliva G (2020) Favorable changes of CT findings in a patient with COVID-19 pneumonia after treatment with tocilizumab. Diagn Interv Imaging 101:323-324. https://doi.org/10.1016/j.diii.2020.03.010

53. Russell B, Moss C, Rigg A, Van Hemelrijck M (2020) COVID-19 and treatment with NSAIDs and corticosteroids: should we be limiting their use in the clinical setting? Ecancermedicalscience 14: 1023. https://doi.org/10.3332/ecancer.2020.1023

54. Martirosyan D, Singh J (2015) A new definition of functional food by FFC: what makes a new definition unique? Funct Foods Heal Dis volume 5:209-223

55. López-Varela S, González-Gross M, Marcos A (2002) Functional foods and the immune system: a review. Eur J Clin Nutr 56:S29 S33. https://doi.org/10.1038/sj.ejcn.1601481

56. Rajkumar RP (2020) Ayurveda and COVID-19: where psychoneuroimmunology and the meaning response meet. Brain Behav Immun 87:8-9. https://doi.org/10.1016/j.bbi.2020.04.056

57. Nyanhanda T, Gould E, Mcghie T, Shaw O, Harper J, Hurst R (2014) Blackcurrant cultivar polyphenolic extracts suppress CCL26 secretion from alveolar epithelial cells. Food Funct 5: 671-677. https://doi.org/10.1039/c3fo60568j

58. Opara EC (2002) Oxidative stress, micronutrients, diabetes mellitus and its complications. J R Soc Promot Heal 122:28-34. https://doi. org/10.1177/146642400212200112 
59. Rayman MP (2000) The importance of selenium to human health. Lancet 356:233-241. https://doi.org/10.1016/S0140-6736(00) 02490-9

60. Kiremidjian-Schumacher L, Roy M (1998) Selenium and immune function. Z Ernahrungswiss 37(Suppl 1):50-56

61. Lozada-Nur F, Chainani-Wu N, Fortuna G, Sroussi H (2020) Dysgeusia in COVID-19: possible mechanisms and implications. Oral Surg Oral Med Oral Pathol Oral Radiol 130:344-346. https:// doi.org/10.1016/j.oooo.2020.06.016

62. Rahman MT, Idid SZ (2020) Can Zn be a critical element in COVID-19 treatment? Biol Trace Elem Res 1-9. https://doi.org/ 10.1007/s12011-020-02194-9

63. Kumar A, Kubota Y, Chernov M, Kasuya H (2020) Potential role of zinc supplementation in prophylaxis and treatment of COVID19. Med Hypotheses 144:109848. https://doi.org/10.1016/j.mehy. 2020.109848

64. Messina G, Polito R, Monda V, Cipolloni L, Di Nunno N, Di Mizio G, Murabito P, Carotenuto M, Messina A, Pisanelli D, Valenzano A, Cibelli G, Scarinci A, Monda M, Sessa F (2020) Functional role of dietary intervention to improve the outcome of COVID-19: a hypothesis of work. Int J Mol Sci 21. https://doi.org/10.3390/ ijms 21093104

65. Somerville VS, Braakhuis AJ, Hopkins WG (2016) Effect of flavonoids on upper respiratory tract infections and immune function: a systematic review and meta-analysis. Adv Nutr 7:488-497. https:// doi.org/10.3945/an.115.010538

66. Pandey KB, Rizvi SI (2009) Plant polyphenols as dietary antioxidants in human health and disease. Oxid Med Cell Longev 2:270 278. https://doi.org/10.4161/oxim.2.5.9498

67. Sordillo PP, Helson L (2015) Curcumin suppression of cytokine release and cytokine storm. A potential therapy for patients with Ebola and other severe viral infections. Vivo 29:1-14

68. Rogero MM, de Leão $M, C$, Santana TM, Pimentel MV de MB, Carlini GCG, da Silveira TFF, Gonçalves RC, Castro IA, (2020) Potential benefits and risks of omega- 3 fatty acids supplementation to patients with COVID-19. Free Radic Biol Med 156:190-199. https://doi.org/10.1016/j.freeradbiomed.2020.07.005

69. Yan F, Polk DB (2011) Probiotics and immune health. Curr Opin Gastroenterol 27:496-501. https://doi.org/10.1097/MOG. 0b013e32834baa4d

70. Martineau AR, Jolliffe DA, Hooper RL, Greenberg L, Aloia JF, Bergman P, Dubnov-Raz G, Esposito S, Ganmaa D, Ginde AA, Goodall EC, Grant CC, Griffiths CJ, Janssens W, Laaksi I, Manaseki-Holland S, Mauger D, Murdoch DR, Neale R, Rees JR, Simpson S, Stelmach I, Kumar GT, Urashima M, Camargo CA (2017) Vitamin D supplementation to prevent acute respiratory tract infections: systematic review and meta-analysis of individual participant data. BMJ 356:i6583. https://doi.org/10.1136/bmj.i6583

71. Grant WB, Lahore H, McDonnell SL, Baggerly CA, French CB, Aliano JL, Bhattoa HP (2020) Evidence that vitamin d supplementation could reduce risk of influenza and covid-19 infections and deaths. Nutrients 12:988. https://doi.org/10.3390/nu12040988

72. Kaur C, Kapoor HC (2001) Antioxidants in fruits and vegetables the millennium's health. Int J Food Sci Technol 36:703-725. https://doi.org/10.1111/j.1365-2621.2001.00513.x
73. Dangour A, Lock K, Hayter A, Aikenhead A, Allen E, Uauy R (2010) Nutrition-related health effects of organic foods: a systematic review. Am J Clin Nutr 92:203-210. https://doi.org/10.3945/ ajcn.2010.29269

74. Newman R, Waterland N, Moon Y, Tou JC (2019) Selenium biofortification of agricultural crops and effects on plant nutrients and bioactive compounds important for human health and disease prevention - a review. Plant Foods Hum Nutr 74:449-460. https:// doi.org/10.1007/s11130-019-00769-z

75. Hemsworth J, Hekmat S, Reid G (2011) The development of micronutrient supplemented probiotic yogurt for people living with HIV: laboratory testing and sensory evaluation. Innov Food Sci Emerg Technol 12:79-84. https://doi.org/10.1016/j. ifset.2010.11.004

76. González-Gallego J, García-Mediavilla MV, Sánchez-Campos S, Tuñón MJ (2010) Fruit polyphenols, immunity and inflammation. Br J Nutr 104:S15-S27. https://doi.org/10.1017/ S0007114510003910

77. Yao LH, Jiang YM, Shi J, Tomás-Barberán FA, Datta N, Singanusong R, Chen SS (2004) Flavonoids in food and their health benefits. Plant Foods Hum Nutr 59:113-122. https://doi. org/10.1007/s11130-004-0049-7

78. Chew BP, Park JS (2004) Carotenoid action on the immune response. J Nutr 134:257S-261S. https://doi.org/10.1093/jn/134.1. $257 \mathrm{~S}$

79. Schulz V, Hänsel R, Tyler VE (2001) Agents that increase resistance to diseases BT - rational phytotherapy: a physicians' guide to herbal medicine. In: Schulz V, Hänsel R, Tyler VE (eds) Springer. Berlin Heidelberg, Berlin, Heidelberg, pp 331-355. https://doi.org/ 10.1007/978-3-642-98093-0_9

80. Ghiamati Yazdi F, Soleimanian-Zad S, van den Worm E, Folkerts G (2019) Turmeric extract: potential use as a prebiotic and antiinflammatory compound? Plant Foods Hum Nutr 74:293-299. https://doi.org/10.1007/s11130-019-00733-x

81. Katayama S, Nishio T, Kishimura H, Saeki H (2012) Immunomodulatory properties of highly viscous polysaccharide extract from the Gagome alga (Kjellmaniella crassifolia). Plant Foods Hum Nutr 67:76-81. https://doi.org/10.1007/s11130-0110271-Z

82. Yousef GG, Grace MH, Medina JLG, Neff S, Guzman I, Brown AF, Raskin I, Lila MA (2014) Concentrating immunoprotective phytoactive compounds from fruits and vegetables into shelfstable protein-rich ingredients. Plant Foods Hum Nutr 69:317324. https://doi.org/10.1007/s11130-014-0445-6

83. Nagai E, Iwai M, Koketsu R, Okuno Y, Suzuki Y, Morimoto R, Sumitani H, Ohshima A, Enomoto T, Isegawa Y (2019) Antiinfluenza virus activity of Adlay tea components. Plant Foods Hum Nutr 74:538-543. https://doi.org/10.1007/s11130-01900773-3

Publisher's Note Springer Nature remains neutral with regard to jurisdictional claims in published maps and institutional affiliations. 